\title{
Deposition of Micro-elements through Leaf Fallen from Different Types of Vegetation, North-eastern Mexico
}

\author{
Tilo G. Dominguez-Gomez ${ }^{1}$, Humberto Gonzalez-Rodriguez ${ }^{1}$, Israel Cantu-Silva ${ }^{1}$, Roque G. Ramirez-Lozano ${ }^{2 *}$, Marco V. \\ Gomez-Meza ${ }^{3}$, Maria Del Socorro Alvarado ${ }^{1}$
}

${ }^{1}$ Universidad Autonoma de Nuevo Leon, Facultad de Ciencias Forestales, Carr. Nac. No 85, km 145. Linares, Nuevo Leon 67700, Mexico

${ }^{2}$ Universidad Autonoma de Nuevo Leon, Facultad de Ciencias Biologicas, Av. Pedro de Alba s/n. San Nicolas de los Garza, Nuevo Leon 66400, Mexico

${ }^{3}$ Universidad Autonoma de Nuevo Leon, Facultad de Economia, Av. Lazaro Cardenas 4600 Ote, Frac. Residencial Las Torres, Monterrey, Nuevo Leon 64930, Mexico

\section{Article History}

Manuscript No. 444a

Received in $20^{\text {th }}$ January, 2014

Received in revised form $28^{\text {th }}$ January, 2014

Accepted in final form $30^{\text {th }}$ January, 2014

\section{Correspondence to}

*E-mail: roque.ramirezlz@uanl.edu.mx

\section{Keywords}

Micronutrients, litterfall, pine forest, oak forest, north-eastern Mexico

\begin{abstract}
The aim of the study was to determine monthly (2007) the content and deposition of $\mathrm{Cu}, \mathrm{Fe}, \mathrm{Mn}$ and $\mathrm{Zn}$ in leaf fallen litterfall samples collected in four sites, northeastern Mexico. Site 1 was located at $1600 \mathrm{~m}$ of altitude in a pine forest, mixed with deciduous trees; site 2 was at $550 \mathrm{~m}$ in the ecotone of a Quercus spp. forest and submontane scrub; sites 3 and 4 (at $350 \mathrm{~m}$ and at $300 \mathrm{~m}$, respectively) were located in the Tamaulipan Thornscrub vegetation. Leaf fallen litterfall samples at each site $\left(2,500 \mathrm{~m}^{2}\right)$ were obtained from ten canisters of $1.0^{2} \mathrm{~m}$ that were randomly situated at each site. The $\mathrm{Cu}$ annual deposition $\left(\mathrm{g} \mathrm{ha}^{-1} \mathrm{yr}^{-1}\right)$ was significantly different among sites being higher in site 4 (23.2) and lower in site 1 (4.1). Fe deposition was also significantly higher in site 4 (522.2) and lower in site 1 (120.0). Mn was higher in site 2 (479.4) and lower in site 1 (64.6). Zn was significantly higher in site 1 (62.8) and lower in site 1 (24.3). Micronutrient annual order deposition was as follows: $\mathrm{Fe}>\mathrm{Mn}>\mathrm{Zn}>\mathrm{Cu}$. Differences in deposition may be attributable to environmental conditions and plant species composition at each studied plant community.
\end{abstract}

\section{Introduction}

In northeastern Mexico there are different types of vegetation such as pine forest, oak forest, the pine-oak forest, and the subtropical woodlands, typical of the semi-arid plains (Vargas, 1999). These ecosystems include a variety of deciduous species used as forage to domestic and wild ruminants; in addition, as forestry resources to human beings, reforestation practices, timber and charcoal production. Therefore, this region provides an opportunity to investigate the nutrient return and biogeochemical cycles as a measure of ecosystem productivity through litterfall deposition (leaves, twigs, inflorescences, fruits, seeds and others) and to characterize their contribution of nutrients to the forest soil.

Litterfall is an important process in the nutrient cycle, which determines the renewal and input of organic matter to the soil (Cantu and Gonzalez, 2001). More than half of the annual absorption of nutrients in the woods is due to the return of litter to soil (Del Valle, 2003). The production and litter decomposition are important mechanisms in the nutrient cycling in vegetation areas (Steubing et al., 2001). Nevertheless, Palma et al. (2000) argue that seasonal differences in production and nutritional quality of litter could be related to extreme climatic fluctuations and/or phenological changes such as abscission and bud initiation, flowering and fruiting.

Deposition of micronutrients from leaves plays an important role through soil covering and modifying its environment. In addition, litterfall decomposition becomes a source of organic matter enhancing the geochemical cycles of elements (Gliessman, 2002). Studies conducted by Del Valle (2003), Vasconcelos and Luizao (2004) and Gonzalez et al. (2008) agreed about the quantities of annual inputs of nutrients through literfall, which are cycled by the leaf fallen litterfall as a main source of organic matter to the forest soil. The leaf component is capable to stock between 30 to $70 \%$ of nutrients since in leaves occur most of the physiological processes, specifically photosynthesis (Piatek and Allen, 2000). 
The decomposition and mineralization of litterfall are given mainly by a limited number of elements, being of great importance some essential nutrients and some heavy metals potentially toxic (Guerrero et al., 1998). Studies on nutrient cycling were conducted in forest areas to gather information about the contribution of litterfall and nutrients (Mlambo and Nyathi, 2007). These studies are limited to the availability of mineral elements such as $\mathrm{Ca}, \mathrm{K}, \mathrm{Mg}, \mathrm{Si}, \mathrm{P}, \mathrm{Fe}, \mathrm{Mn}, \mathrm{B}, \mathrm{Cl}$, $\mathrm{Mo}, \mathrm{Zn}, \mathrm{Na}$ and $\mathrm{Co}$. However, few studies are focused to quantitate the amount of micronutrient deposition in different plant communities of the northeastern region of Mexico. Therefore, the aim of this research was to assess the content and deposition of micronutrients through leaf fallen in diverse types of vegetation.

\section{Materials and Methods}

\subsection{Sites of study}

This study was carried out at four undisturbed grazing sites located in the state of Nuevo Leon, northeastern Mexico. Site 1 was located in the pine (Pinus pseudostrobus Lindl.) forest mixed with deciduous trees (Quercus spp) located at the Experimental Forest Research Station of the Universidad Autonoma de Nuevo Leon in the Sierra Madre Oriental Mountain Range, Iturbide county $\left(24^{\circ} 43^{\prime} \mathrm{N}\right.$; $99^{\circ} 52^{\prime} \mathrm{W} ; 1600$ $\mathrm{m}$ of altitude). Annual mean air temperature is about $14{ }^{\circ} \mathrm{C}$, average annual rainfall is approximately $639 \mathrm{~mm}$ (INEGI, 2002). The soils are mainly rocky and comprise upper cretaceous lutite or siltstone. Site 2 was located in the ecotone of a Quercus spp. forest and the Piedmont scrub vegetation $\left(24^{\circ}\right.$ $46^{\prime} \mathrm{N} ; 99^{\circ} 41^{\prime} \mathrm{W}$; $550 \mathrm{~m}$ of altitude) in the "Ejido Crucitas" in Linares county. Average total annual rainfall is about $755 \mathrm{~mm}$ (INEGI, 2002). Site 3 was located at the Experimental Research Station of the Faculty of Forest Sciences of the Universidad Autonoma de Nuevo Leon $\left(24^{\circ} 47^{\prime} \mathrm{N}\right.$; $99^{\circ} 32^{\prime} \mathrm{W}$; $350 \mathrm{~m}$ of altitude) in Linares county. Average total annual rainfall is about $805 \mathrm{~mm}$ (INEGI, 2002). Peak rainfall months are May, June, and September (Gonzalez-Rodriguez et al., 2004). Site 4 was located in the "Ejido Hacienda de Guadalupe" in Linares county $\left(24^{\circ} 54^{\prime} \mathrm{N}\right.$; $99^{\circ} 32^{\prime} \mathrm{W}$; elevation, $300 \mathrm{~m}$ of altitude). Total cumulative annual rainfall is about $672 \mathrm{~mm}$. Vegetation of sites 2 and 3 is known as the Tamaulipan Thornscrub or Subtropical Thornscrub Woodlands. In the last three sites, the climate is subtropical and semiarid with warm summer, monthly mean air temperature ranges from $14.7^{\circ} \mathrm{C}$ in January to $22.3{ }^{\circ} \mathrm{C}$ in August, although daily high temperatures of $45^{\circ} \mathrm{C}$ are common during summer. The dominant soils are deep, dark-gray, limegray, lime-clay vertisols, with montmorillonite, which shrink and swell noticeably in response to changes in soil moisture content (Gonzalez et al., 2011).

\subsection{Litterfall sampling}

An experimental plot $\left(2,500 \mathrm{~m}^{2}\right)$ was delimited at each studied site. At each site, ten canisters of $1.0 \times 1.0 \mathrm{~m}$ were randomly scattered inside the plot. Canisters were made of a wooden beveled frame $(10 \mathrm{~cm})$ with a plastic mesh $(1.0 \mathrm{~mm})$ on the bottom. The canisters were placed at $0.30 \mathrm{~m}$ above soil surface, in this way throughfall is allowed to pass thru. In this study, the sampling area, number of canisters, and height above soil level are within the range of previous studies (Fang et al., 2007; Zhou et al., 2007). The frequency of litter sampling was at intervals of 30 days between December 21, 2006 and December 20, 2007. Dry weight of samples was determined by drying samples at $65^{\circ} \mathrm{C}$ for 72 hours until constant weight using a forced air oven. The weight of each sample was determined using a digital scale (Sartorius Brand, Model C1), with a resolution of a thousandth of a gram. Dry samples were ground in a Wiley mill (Thomas Scientific) to pass $1.0 \mathrm{~mm}$ mesh sieve and were kept in closed paper envelopes.

\subsection{Chemical analyses}

Since both, macro- $(\mathrm{Ca}, \mathrm{K}, \mathrm{Mg}, \mathrm{P}$, and $\mathrm{N})$ and micro-nutrients $(\mathrm{Cu}, \mathrm{Fe}, \mathrm{Mn}$ and $\mathrm{Zn})$ play essential roles in plant cell metabolism and plant life cycle, most of the total litterfall is constituted mainly by leaves (from $74 \%$ to $86 \%$, on a yearly basis), and because the contribution of each litterfall component deposition and macronutrient deposition through leaves have been previously documented at research sites by Gonzalez et al. (2011), it was widely considered by the authors of this research paper to know and to document the content and deposition pattern of micronutrients on a monthly as well as on a yearly basis, since very little information is available of this kind.

By quintuplicate, $2.0 \mathrm{~g}$ of leaf litter samples collected from each canister were subjected to micronutrients analysis. Firstly, leaf samples were incinerated during $5 \mathrm{~h}$ in a furnace at $550^{\circ} \mathrm{C}$. Ashes were digested by the wet digestion technique using a solution containing $\mathrm{HCl}$ and $\mathrm{HNO}_{3}$ (Cherney, 2000). Contents ( $\mu \mathrm{g} \mathrm{g}^{-1}$ dry weight) of $\mathrm{Cu}, \mathrm{Fe}, \mathrm{Mn}$ and $\mathrm{Zn}$ (air flame/acetylene) were determined by atomic absorption spectrophotometry using a Varian spectrophotometer (model SpectrAA-200). Micronutrient deposition $\left(\mathrm{mg} \mathrm{m}^{-2}\right)$ at each site was calculated by multiplying leaf fallen production of each sampling date by the mineral content of the corresponding date of sampling, site, replication, and adding them over the entire year. The cumulative monthly values at each site were used as an estimate of the annual micronutrient deposition ( $\left.\mathrm{mg} \mathrm{ha}^{-1} \mathrm{yr}^{-1}\right)$.

\subsection{Statistical analyses}

Data of micronutrient content and deposition were subjected to one-way analysis of variance (Steel and Torrie, 1980). Normal distribution and homogeneity of variances of deposition and micronutrient content data were analyzed by using the 
Kolmogorov-Smirnov, Shapiro-Wilk, and Levene tests (Brown and Forsythe, 1974; Steel and Torrie, 1980) indicating that deposition and micronutrient content data were non-normally distributed. Since for most sampling dates, ANOVA did not show the assumption of equality of variances, the KruskalWallis nonparametric test was employed (Ott, 1993) to detect significant differences among sites at each sampling date. Hence, differences in micronutrient content and deposition among sites were validated using the Mann-Whitney U nonparametric test with the Bonferroni's correction method at $p=0.05$ (Wackerly et al., 2002). All applied statistical methods were according to the SPSS 2000; (Statistical Package for the Social Sciences) software package (standard released version 13.0 for Windows, SPSS Inc., Chicago, IL).

\section{Results and Discussion}

\subsection{Monthly microelement content of fallen leaves}

The $\mathrm{Cu}$ content ( $\mu \mathrm{g} \mathrm{g}^{-1}$ of dry weight; Figure 1a) in site 1 ranged from 1.5 (May) to 5.3 (February); in site 2, from 4.2 (October) to 8.3 (April); in site 3, from 3.3 (January) to 6.8 (April); and in site 4, from 6.0 (July) to 11.2 (March). Leaf litter Fe content ( $\mu \mathrm{g} \mathrm{g}^{-1}$ of dry weight; Figure $1 \mathrm{~b}$ ) in site 1 varied from 57.8 (March) to 101.8 (April); for site 2, from 44.7 (March) to 262.4 (December); for site 3, from 81.7 (February) to 208.7 (July); and for site 4, from 114.7 (January) to 325.9 (June). The Mn content ( $\mu \mathrm{g} \mathrm{g}^{-1}$ of dry weight; Figure 1c) in site 1 varied from 16.1 (May) to 177.3 (March); for site 2, from 87.79 (June) to 263.0 (October); for site 3, from 26.83 (April) to 36.0 (July); and for site 4, from 56.2 (November) to 110.6 (January). The $\mathrm{Zn}$ content ( $\mu \mathrm{g} \mathrm{g}^{-1}$ of dry weight; Figure 1d) of site 1 ranged from 10.7 (December) to 30.0 (September); in site 2, from 7.5 (March) to 26.4 (June); in site 3, from 12.2 (June) to 25.0 (September); and in site 4, from 15.0 (July) to 29.3 (February).

\subsection{Monthly deposition of microelements}

The $\mathrm{Cu}$ deposition $\left(\mathrm{mg} \mathrm{m}^{-2}\right.$; Figure $\left.2 \mathrm{a}\right)$ in site 1 , ranged from 0.01 (January) to 0.10 (November); in site 2, from 0.05 (May) to 0.18 (September); in site 3, from 0.06 (July) to 0.28 (December); and in site 4, from 0.03 (May) to 0.46 (November). Leaf litter Fe deposition ( $\mathrm{mg} \mathrm{m}^{-2}$; Figure $\left.2 \mathrm{~b}\right)$ in site 1 varied from 0.21 (February) to 1.88 (November); for site 2, from 0.50 (May) to 4.72 (December); for site 3, from 1.35 (May) to 7.80 (September); and site 4, from 0.71 (May) to 13.5 (August). The Mn deposition ( $\mathrm{mg} \mathrm{m}^{-2}$; Figure $\left.2 \mathrm{c}\right)$ in site 1 varied from 0.15 (May and July) to 1.14 (November); for site 2, from 0.97 (June) to 10.4 (September); for site 3, from 0.34 (June) to 1.37 (December); and for site 4, from 0.34 (May) to 3.02 (February). The $\mathrm{Zn}$ deposition ( $\mathrm{mg} \mathrm{m}^{-2}$; Figure $2 \mathrm{~d}$ ) for site 1 ranged from 0.3 (February) to 0.40 (November); in site
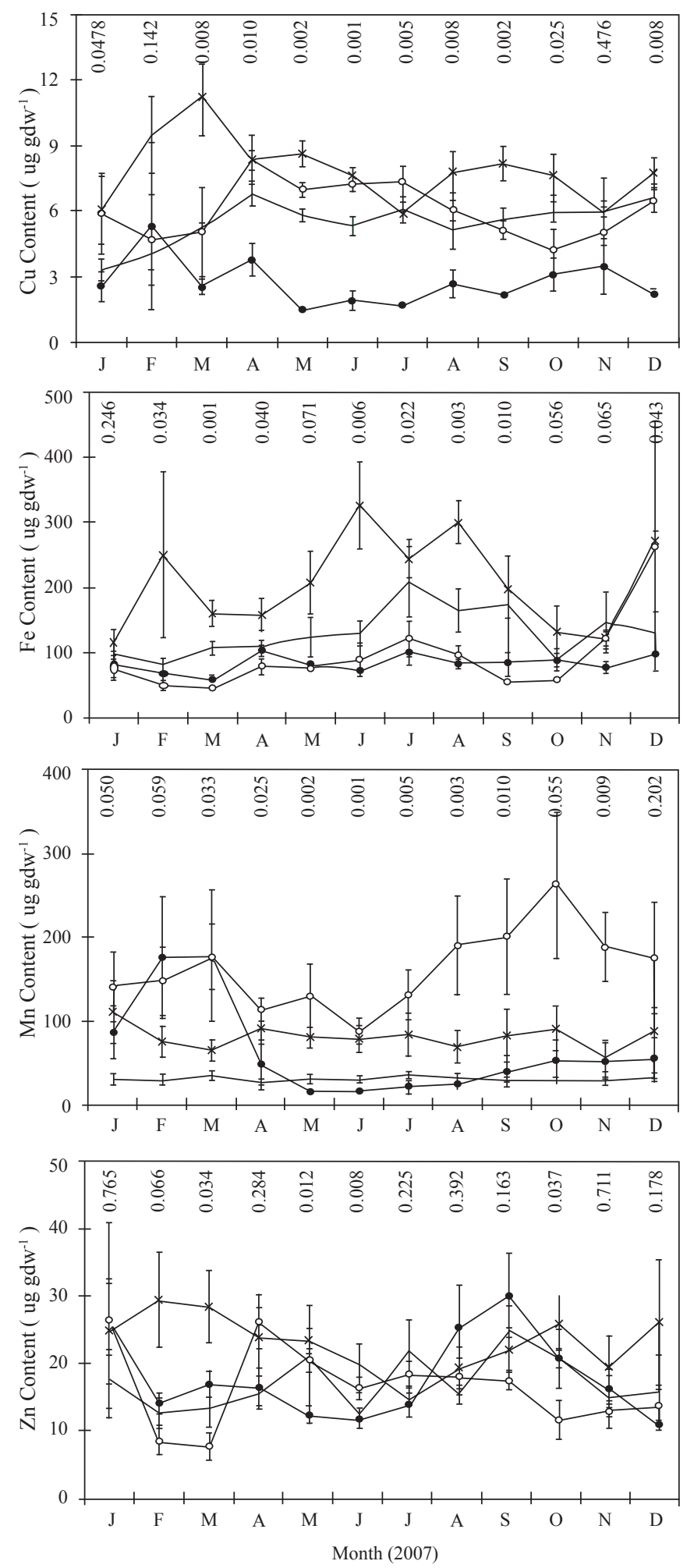

Figure 1: Monthly variations of $\mathrm{Cu}, \mathrm{Fe}, \mathrm{Mn}$, and $\mathrm{Zn}$ contents in leaf fallen litter at research sites. $P$-values of the Kruskal-Wallis test to detect significant differences among sites are shown at each sampling date within the graph. $P$-values $\leq 0.001$ are denoted as 0.001 . Statistically significant probabilities $(P \leq 0.05)$ are shown in boldface. $\bullet=$ site $1, \circ=$ site $2,-=$ site $3, \times=$ site 4 
2, from 0.13 (May) to 0.64 (September); in site 3, from 0.17 (March) to 0.89 (September); and in site 4, from 0.09 (July) to 1.37 (February).

\subsection{Annual deposition of microelements}

Annual deposition of $\mathrm{Cu}$ ranged from 4.1 (Site 1; Table 1) to $23.2 \mathrm{~g} \mathrm{ha}^{-1} \mathrm{yr}^{-1}$ (site 4); Fe from 120 (site 1) to $522.1 \mathrm{~g} \mathrm{ha}^{-1}$ $\mathrm{yr}^{-1}$ (site 4); Mn from 64.4 (site 3) to $479.4 \mathrm{~g} \mathrm{ha}^{-1} \mathrm{yr}^{-1}$ (site 2); and $\mathrm{Zn}$ from 24.3 (site 1) to $62.8 \mathrm{~g} \mathrm{ha}^{-1} \mathrm{yr}^{-1}$ (site 4). The total annual contribution $(\mathrm{Cu}+\mathrm{Fe}+\mathrm{Mn}+\mathrm{Zn})$ in the site $1,2,3$ and 4 was of 213.0, 738.1, 522.2 and $822.9 \mathrm{~g} \mathrm{ha}^{-1} \mathrm{yr}^{-1}$, respectively. In general, the order of deposition of trace elements was $\mathrm{Fe}>\mathrm{Mn}>\mathrm{Zn}>\mathrm{Cu}$.

According to micronutrient contents, the order of magnitude was as follows: $\mathrm{Fe}>\mathrm{Mn}>\mathrm{Zn}>\mathrm{Cu}$, and by site was: site $4>$ site $2>$ site $3>$ site 1 . The annual $\mathrm{Cu}$ deposition via leaf litter was in the following decreasing order: site $4>$ site $3>$ site $2>$ site 1 . The extreme low and high of total annual $\mathrm{Cu}$ depositions were in site 1 , with 4.1 and in site 4 with $23.2 \mathrm{~g} \mathrm{ha}^{-1} \mathrm{yr}^{-1}$. Higher $\mathrm{Cu}$ deposition values, in different plant communities, that varied from 40 to $90 \mathrm{~g} \mathrm{ha}^{-1} \mathrm{yr}^{-1}$ were reported by Del Valle (2003), Gonzalez et al. (2006) and Ramirez et al. (2007). With respect to $\mathrm{Fe}$, the decreasing order of total annual deposition was: site $4>$ site $3>$ site $2>$ site 1 with a range from 120 (site 1) to 522 (site 4) $\mathrm{g} \mathrm{ha}^{-1} \mathrm{yr}^{-1}$. Gonzalez et al. (2006) found a Fe deposition range between 607 and $1,965 \mathrm{~g} \mathrm{ha}^{-1} \mathrm{yr}^{-1}$ when they studied micronutrient deposition in the Tamaulipan thornscrub in the northeastern region of Mexico. In another study, Ramirez et al. (2007) reported Fe depositions of 700, 630 and $420 \mathrm{~g} \mathrm{ha}^{-1}$ $\mathrm{yr}^{-1}$ in an oak, Pinus patula and cypress forests, respectively. Del Valle (2003) observed a Fe deposition value of $730 \mathrm{~g} \mathrm{ha}^{-1}$ $\mathrm{yr}^{-1}$. Xiaoniu et al. (2004) documented values of $860 \mathrm{~g} \mathrm{ha}^{-1} \mathrm{yr}^{-1}$ in a subtropical forest in Okinawa Island, Japan. The annual deposition of Mn among sites was in the following order: site $2>$ site $4>$ site $3>$ site 1 . Mn annual deposition ranged from 64.6 (site 1) to 479.4 (site 2) $\mathrm{g} \mathrm{ha}^{-1} \mathrm{yr}^{-1}$. Gonzalez et al. (2006) studied the micronutrient deposition in the Tamaulipan Thornscrub and reported a Mn deposition from 131 to $275 \mathrm{~g} \mathrm{ha}^{-1} \mathrm{yr}^{-1}$ while Hagen et al. (2006) found a range of deposition between 270 and $458 \mathrm{~g} \mathrm{ha}^{-1} \mathrm{yr}^{-1}$ in a Quercus robur forest. Similarly, Xiaoniu

Table 1: Annual micronutrient deposition $\left(\mathrm{g} \mathrm{ha}^{-1} \mathrm{yr}^{-1}\right)$ through leaf litterfall at each research site.

\begin{tabular}{lcccc}
\hline \multirow{2}{*}{$\begin{array}{l}\text { Deposi- } \\
\text { tion }\end{array}$} & \multicolumn{4}{c}{ Sites } \\
\cline { 2 - 5 } & 1 & 2 & 3 & 4 \\
\hline $\mathrm{Cu}$ & 4.1 & 14.1 & 15.4 & 23.2 \\
$\mathrm{Fe}$ & 120.0 & 206.7 & 378.1 & 522.1 \\
$\mathrm{Mn}$ & 64.6 & 479.4 & 82.3 & 214.8 \\
$\mathrm{Zn}$ & 24.3 & 37.6 & 46.4 & 62.8 \\
Total & 213.0 & 738.1 & 522.2 & 822.9 \\
\hline
\end{tabular}
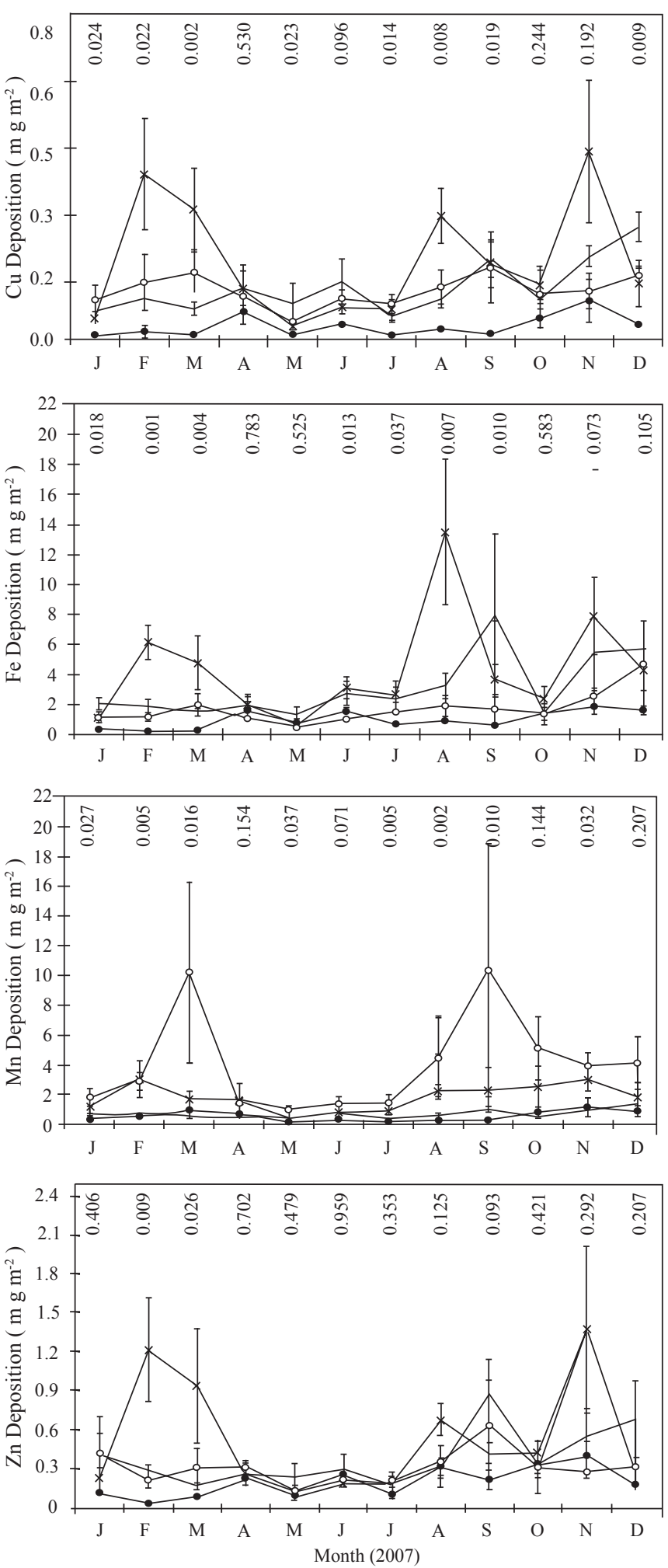

Figure 2: Monthly variations of $\mathrm{Cu}, \mathrm{Fe}, \mathrm{Mn}$, and $\mathrm{Zn}$ deposition in leaf fallen litter at research sites. $P$-values of the Kruskal-Wallis test to detect significant differences among sites are shown at each sampling date within the graph. $p$-values $\leq 0.001$ are denoted as 0.001 . Statistically significant probabilities $(P \leq 0.05)$ are shown in boldface. $\bullet=$ site $1,0=$ site $2,-=$ site $3, \times=$ site 4 . 
et al. (2004) observed Mn deposition values of about $391 \mathrm{~g}$ $\mathrm{ha}^{-1} \mathrm{yr}^{-1}$ in a subtropical forest. In contrast, Del Valle (2003) reported values of $930 \mathrm{~g} \mathrm{ha}^{-1} \mathrm{yr}^{-1}$ in Mn deposition in South of Colombia. The annual deposition of $\mathrm{Zn}$ decreased among sites as follows: site $4>$ site $3>$ site $2>$ site 1 with values that varied from 24.3 (site 1) to 62.8 (site 4) $\mathrm{g} \mathrm{ha}^{-1} \mathrm{yr}^{-1}$. Del Valle (2003) found deposition values of $230 \mathrm{~g} \mathrm{ha}^{-1} \mathrm{y}^{-1}$ and Ramirez et al. (2007) reported 75, 105, and $70 \mathrm{~g} \mathrm{ha}^{-1} \mathrm{yr}^{-1}$ in Oak, Pinus patula and cypress, forest ecosystems, respectively, in Colombia. Studies undertaken in the Tamaulipan thornscrub vegetation, northeast Mexico, by Gonzalez et al. (2006) documented a deposition of $\mathrm{Zn}$ from 28.2 to $540 \mathrm{~g} \mathrm{ha}^{-1} \mathrm{yr}^{-1}$. In present study, for a given site, $\mathrm{Cu}$ and $\mathrm{Zn}$ deposition values showed a similar trend during the experimental period; however, $\mathrm{Fe}$ and $\mathrm{Mn}$ exhibited major peaks and a higher variability in figures. These results may allow to hypothesizes that high Fe and $\mathrm{Mn}$ content may be associated with translocation processes through leaves just before foliar abscission takes place or the promotion of phenological events. In addition, higher content and deposition values of $\mathrm{Fe}$ and $\mathrm{Mn}$ could be associated to resource availability, which lead to high absorption of these micronutrients, particularly in sites 2 and 4 . This rational could be used in further research objectives, although nutrient content was not estimated in other litterfall components such as twigs and reproductive structures to find out nutrient allocation and compartmentalization. It has been demonstrated that nutrient concentration is higher in leaves than other litterfall constituents (Yang et al., 2006). Nevertheless, nutrient deposition depends on tissue age, type of structure being studied, season, herbivory, edaphic features and prevailing environmental conditions at research sites (Gliessman, 2002).

\section{Conclusions}

Results of present study showed a spatial and temporal variation in the content and deposition of micronutrients in the litterfall in the four studied sites and the potential contribution of nutrients varied among plant communities. In addition, the findings of this research confirm the importance of deposition of microelements through leaves, to maintain forest ecosystem productivity. However, further nutrient deposition studies are required to quantitate the contribution of other litterfall components in order to understand the dynamic of biogeochemical cycles in forest ecosystems.

\section{Acknowledgments}

This research was funded in part by Universidad Autonoma de Nuevo Leon (PAICYT grants CN905-04 and CN133-05) and Consejo Nacional de Ciencia y Tecnologia, grant No 204564.

\section{References}

Brown, M.B., Forsythe, A.B., 1974. Robust tests for the equality of variances. Journal of the American Statistical Association 69(346), 364-367.

Cantu, S.I., Gonzalez, H.R., 2001. Interception loss, throughfall and stem flow chemistry in pine and oak forests in northeastern Mexico. Tree Physiology 21(12-13), 10091013.

Cherney, D.J.R., 2000. Characterization of forages by chemical analysis. In: Givens, D.I., Owen, E., Axford., R.F.E., Omed, H.M. (Eds.), Forage evaluation in ruminant nutrition. CAB International, Wallingford, 281-300.

Del Valle, A.J.I., 2003., Cantidad, calidad y nutrientes reciclados por la hojarasca fina de bosques pantanosos del pacifico sur Colombiano. Interciencia 28(8), 443-449.

Fang, J.Y., Liu, G.H., Zhu, B., Wang, X.K., Liu, S.H., 2007. Carbon budgets of three temperate forest ecosystems in Dongling Mt., Beijing, China. Science China Earth Science 50(1), 92-101.

Gliessman, R.S., 2002. Agroecologia: Proceso ecologicos en agricultura sostenible. Turrialba, Costa Rica: AGRUCOCATIE, 358.

Gonzalez, R.H., Cantu, S.I., Gomez, M.M.V., Ramirez, L.R.G., 2004. Plant water relations of thornscrub shrub species, northeastern Mexico. Journal of Arid Environments 58(4), 483-503.

Gonzalez, R.H., Cantu, S.I., Gomez, M.M.V., Ramirez, L.R.G., Uvalle, S.J.I., 2006. Produccion de hojarasca y reciclado de nutrientes en el Matorral Espinoso Tamaulipeco en el Noreste de Mexico. In: Memoria del $2^{\text {do }}$ Congreso Latinoamericano IUFRO. Octubre 23-27 de 2006. La Serena, Chile, 296.

Gonzalez, RH., Cantu, S.I., Ramirez, L.R.G., Gomez, M.M.V., Dominguez, G.T.G., Bravo, G.J., Maiti, R.K., 2008. Spatial and seasonal litterfall deposition pattern in the Tamaulipan thorscrub, Northeastern Mexico. International Journal of Agriculture Environment and Biotechnology 1(4), 177-181.

Gonzalez, R.H., Dominguez, G.T.G., Cantu, S.I., Gomez, M.M.V., Ramirez, L.R.G., Pando, M.M., Fernández, C.J., 2011. Litterfall deposition and leaf litter nutrient return in different locations at Northeastern Mexico. Plant Ecology 212(10), 1747-1757.

Guerrero, C.J., Camarero, J.J., Gutierrez, E., 1998. Crecimiento estacional y caida de aciculas en Pinus sylvestris y $P$. uncinata. Investigacion Agraria Sistemas y Recursos Forestales 7(1-2), 156-172.

Hagen, T.A., Varnagiryte, I., Nihlgard, B., Armolaitis, K., 2006. Autumn nutrient resorption and losses in four deciduous forest tree species. Forest Ecology and Management 
228(1-3), 33-39.

Instituto Nacional de Estadistica Geografia e Informatica (INEGI), 2002. Instituto Nacional de Estadistica, Geografia e Informatica "Uso actual del suelo en los nucleos agrarios. Aspectos geograficos de Nuevo Leon", México. http://nl.inegi.gob.mx/territorio/espanol/cartcat/ uso.html.(20 de mayo del 2009).

Mlambo, D., Nyathi, P., 2007. Litterfall and nutrient return in a semi-arid Southern African savanna woodland dominated by Colophospermum mopane. Plant Ecology 196(1), 101-110.

Ott, L., 1993. An introduction to statistical methods and data analysis. $\left(2^{\text {nd }} E d n\right)$. Boston, Massachusetts USA: Duxbury Press, 775.

Palma, R.M., Defrieri, R.L., Tortarolo, M.F., Prause, J., Gallardo. J.F., 2000. Seasonal changes of bioelements in the litter and their potential return to green leaves in four species of the Argentine subtropical forest. Annals of Botany 85(2), 181-186.

Piatek, B.K., Allen, H.L., 2000. Site preparation effects on foliar $\mathrm{N}$ and $\mathrm{P}$ use, retranslocation, and transfer to litter in 15-years old Pinus taeda. Forest Ecology and Management 129(1-3), 143-152.

Ramirez, C.J.A., Zapata, D.C.M., Leon, P.J.D., Gonzalez, H.M.I., 2007. Caida de hojarasca y retorno de nutrientes en bosques montanos andinos de Piedras Blancas, Antioquia, Colombia. Interciencia 32(5), 303-311.

SPPS, 2000. Statistical Package for the Social Sciences. Standard released (version 13 for Windows), SPPS Inc., Chicago, IL. USA.
Steel, G.D.R., Torrie, J.H., 1980. Principles and procedures of statistics. A biometrical approach, ( $\left.2^{\text {nd }} E d n\right)$. McGrawHill Book Company. New York, USA, 625.

Steubing, L., Godoy, R., Alberdi, M., 2001. Metodos de Ecologia Vegetal. Santiago, Chile: Universitaria, 345.

Vargas, L.B., 1999. Caracterizacion de la productividad y estructura de Pinus hartwegii Lindl en tres gradientes altitudinales en el cerro Potosi, Galeana, Nuevo Leon. Tesis de Maestria. Facultad de Ciencias Forestales. UANL. Linares, Nuevo Leon, Mexico, 93.

Vasconcelos, L.H., Luizao, F.J., 2004. Litter production and litter nutrient concentrations in a fragmented Amazonian Landscape. Ecology Applied 14(3), 884-892.

Wackerly, D.D., Mendenhall, W., Scheaffer, R.L., 2002. Estadistica matematica con aplicaciones. ( $\left.6^{\text {ta }} \mathrm{Ed}\right)$. Thomson International, Mexico, D.F, 853.

Xiaoniu, X., Hirata, E., Shibata, H., 2004. Effect of typhoon disturbance on fine litterfall and related nutrient input in a subtropical forest on Okinawa Island, Japan. Basic Applied Ecology 5(3), 271-282.

Yang, W.Q., Wang, K.Y., Kellomaki, S., Zhang, J., 2006. Annual and monthly variations in litter macronutrients of three subalpine forests in Western China. Pedosphere 16(6), 788-798.

Zhou, G., Guan, L., Wei, X., Zhang, D., Zhang, Q., Yan, J., Wen, D., Liu, J., Liu, S., Huang, Z., Kong, G., Mo, J., Yu, Q., 2007. Litterfall production along successional and altitudinal gradients of subtropical monsoon evergreen broadleaved forests in Guangdong, China. Plant Ecology 188(1), 77-89. 